\title{
The moderating effect of exploitative and exploratory learning on internationalisation-performance relationship in SMEs
}

\author{
Ivan De Noni, ivan.denoni@unimi.it, University of Milan ${ }^{*}$ \\ Roberta Apa, roberta.apa@unipd.it, University of Padua
}

\begin{abstract}
The internationalisation of small and medium enterprises (SMEs) is an increasing phenomenon but the effective advantages of internationalisation have been disputed yet. This study extends internationalisation research by focusing on learning perspective to investigate the relationship between firm's internationalisation and performance. Specifically, a path regression model is applied to examine how exploitative and exploratory learning is able to moderate SMEs' exporting process to drive business performance. The differences in organisational learning are further investigated compared to domestic firms. The findings suggest exploitation does not affect SMEs' internationalisationperformance link but it is likely a critical antecedent to efficiently move to global markets, while exploration plays a significant role to positively leverage the effect of international involvement on business performance.
\end{abstract}

\section{Second abstract}

Aunque la internacionalizaciòn de las pequeñas y medianas empresas (PYME) es un fenomeno cada vez màs extendido, todavia hay muchas dudas sobre sus reales beneficios en terminos de rendimientos financieros. Este estudio contribuye a la investigación sobre la internacionalizaciòn analizando la relaciòn entre la internacionalizaciòn $\mathrm{y}$ el rendimiento desde una perspectiva basada en el aprendizaje. En primer lugar, se ha realizado una comparaciòn entre empresas internacionales y empresas locales para evaluar la existencia de diferentes niveles de aprendizaje. Despuès, un modelo de análisis de senderos ha sido implementado para estudiar el rol del aprendizaje de explotación y exploración para moderar el

For correspondence: Department of Economics, Management and Quantitative Methods, via Conservatorio 7, 20122, Milan, Italy. 
efecto del proceso de exportaciòn de los rendimientos de las PYME. Los resultados demuestran, por una parte, que el aprendizaje de explotación no afecta en la relaciòn entre la internacionalizaciòn y el rendimiento y podria ser màs bien una condiciòn previa para acceder al mercado global, y por otro lado, al contrario, el aprendizaje de exploración favorecido del aumento de la implicaciòn internacional genera efectos positivos sobre los rendimientos financieros de empresas

\section{Keywords}

Internationalisation, exporting, exploitative and exploratory learning, business performance, SMEs.

\section{Summary Highlights}

Contributions: Since the uncertainty related to internationalisation-performance relationship for both small and large businesses, this study focuses on SMEs' internationalisation in order to examine the role of exploitative and exploratory learning in leveraging the effect of exporting process on financial performance.

Purpose/Research Question: Does international involvement of SMEs affect their business performance? What is the role of learning on internationalisationperformance link? Are the exporting SMEs more learning oriented than domestic ones? And, more specifically, how does the exploitative and exploratory learning moderate the effect of SMEs' exporting on business performance?

Findings/Results: Path regression model is implemented to test our hypotheses using data from 311 Italian SMEs mainly in the manufacturing and construction industries. We find that the exporting SMEs are more exploitative and exploratory learning oriented than domestic ones. However, while exploratory learning strongly influences the effect of international involvement on performance, exploitative learning is mainly to be considered as a significant antecedent to successfully move to foreign markets.

Limitations: While providing interesting insights, our study is limited in terms of the sample number and geo-distribution, and the measures operationalized in the study.

Theoretical Implications and Recommendations: This study contributes new empirical evidence of the relationship between internationalisation and business performance in SMEs. Accordingly the authors, looking at moderating role of learning is crucial to enhance business performance through internationalisation.

Practical Implications and Recommendations: In early internationalisation, policy makers have to support entrepreneurs in developing adequate organisational 
competences and routines to move to global markets. Then, regional policies have to sustain SMEs' international involvement and exploratory learning by encouraging external knowledge assimilation and by providing proactive platforms to foster the creation of trustful and cooperative networks with foreign customers, suppliers and partners.

\section{Introduction}

The economic crisis has recently highlighted the disruptive effects of international competition on local productive systems and the need to support the sustainable growth of domestic firms by improving business models, managerial and corporate competences, technological innovation and organisational learning capabilities and marketing policies to foster the firms' global involvement and competitiveness. In this context, policy makers are investing large amounts of public funds in sustaining the internationalisation of small and medium enterprises (SMEs), because of the confidence that access to the global market is able to enhance the regional growth and development. However, forty years of theoretical and empirical studies have not yet been sufficient to allow for the claim that the degree of internationalisation positively contributes to firms' performances. Different theories try to explain the effectiveness of the internationalisation process and many factors have been introduced to rationalise it. The result is a range of heterogeneous findings (Ruigrok \& Wagner 2004; Bausch \& Krist 2007; Glaum \& Oesterle 2007) in which the sign and shape of the relationship between internationalisation and performance has not been clear yet.

In the last decades, learning perspective of internationalisation highlighted the role of learning in leveraging the relationship between SMEs' international involvement and business performance (Johanson \& Vahlne 1977, 2003; Eriksson et al. 1997; Li et al. 2004; Jansson \& Sandberg 2008; Casillas et al. 2009). Recently, Hsu and Pereira (2008) and Zahra and Hayton (2008) have empirically verified the moderating effect of organisational learning and absorptive capacity on the internationalisation-performance link for multinational enterprises (MNE). However, none has tested this moderating influence for small and medium firms. Therefore, learning perspective is adopted to fill this gap. Resource-based and network-based approaches are then specifically assumed to define and distinguish exploitative and exploratory values affecting learning (March, 1991; Zahra \& George, 2002). On one hand, exploitative learning depends on the firm's ability to employ organisational resources and competences for developing internal knowledge; on the other hand, exploratory learning depends on the ability to access and acquire new knowledge through relational capital and enlarged 
international networks. Moreover, in despite of multiple internationalisation forms, this paper emphasizes SMEs' internationalisation from exporting perspective because exporting is traditionally the more privileged entry mode for small firms (Ramaswamy et al. 1996; Leonidou \& Katsikeas 1996; Majocchi \& Zucchella 2003).

According to this approach, this study mainly contributes to internationalisation research in two ways. First, we explore if international SMEs are more learning oriented than domestic firms are. Second, we analyse the moderating impact of exploitative and exploratory learning in leveraging the effect of internationalisation process on SMEs' financial performance.

Methodologically, the research involves a sample of 311 Italian SMEs, both domestic and internationalised firms, which are homogenously located within Emilia Romagna region and which mainly belong to the manufacturing and construction industries. Data are provided by National Confederation of Crafts and Small and Medium Sized Businesses - CNA Regional Association of Emilia Romagna. Path regression analysis is implemented to investigate both the direct effect of internationalisation on business performance and the moderating effect through exploitative and exploratory learning.

The empirical findings firstly show that exploitative learning positively affects business performance of domestic firms while exploratory learning is more critical for exporting SMEs. Secondly, only the exploratory learning efficiently moderates the effect of international involvement on performance. This suggests that a proactive exploratory learning enhances the effect of exporting on financial performance and increases SMEs' competitiveness in global markets. Conversely, even though exporting SMEs are more exploitative learning oriented compared to domestic firms, the insignificance of international involvement on exploitative learning suggests organisational competences and routines are likely an antecedent for successfully moving toward foreign markets rather than depending on the internationalisation process.

The paper is organised as follows. In the first section, the theoretical background is defined and argued. Firstly, the ambiguous nature of internationalisationperformance link is discussed. Secondly, the moderating role of exploitative and exploratory learning on the relationship between internationalisation and performance is investigated and research hypotheses are suggested. The second section describes data sources, samples, variables and results of path regression model. A discussion of the findings is presented in the third section, while conclusions, implications, limitations and suggestions for further research are shown in the final section. 


\section{Theoretical background}

\subsection{The conflicting relationship between internationalisation and performance}

Almost all theories of internationalisation suggest that it contributes to enhance the competitiveness of firms and their performance. However, the range of arguments applied to justify such a claim varies across theories. According to the industrial organisation perspective, internationalised firms benefit from the exploitation of asymmetries and imperfections in international markets (Williamson 1979), economies of scale and scope (Hymer 1976; Capar \& Kotabe 2003), delocalisation of activities in countries in which the costs of inputs are lower or legislation is permissive (Dunning 1981) and the spreading of entrepreneurial and market risk across countries (Teece 1983). According to the resource-based view, internationalisation contributes to the performance of firms by improving the exploitation of core competencies that were formed in a specific local setting (Sharma \& Blomstermo 2003; Ahokangas 1998; Prahalad \& Hamel 1990). The network perspective focuses on the role of networks in leveraging the capacity of firms in internationalising their activities and taking advantage of the opportunities in foreign and transnational markets (Jansson \& Sandberg 2008; Etemad \& Lee 2003). Finally, according to the knowledge-based perspective, internationalised firms are exposed to a larger number and more diversified set of stimuli and information. This contributes to enhance the competitiveness of firms by broadening their knowledge base and improving their core competencies (Johanson \& Vahlne 2003; Knight \& Liesch 2002). In the internationalisation stage theory (Johanson \& Vahlne 1977, 2003), SMEs' involvement in and commitment to internationalisation depend on their capacity for experiential learning and knowledge acquisition.

Even though theoretical approaches generally emphasise the potential benefits of internationalisation, Hennart (2007) criticises some aspects of the theoretical rationale is below the internationalisation-performance link by highlighting the unclear effect of international diversification on internationalisation advantages related to scale economies, flexibility and learning. The empirical researches further increase this emerging uncertainty due to the lack of providing consistent evidence of the existence and the shape of a positive relationship between internationalisation and performance. Numerous scholars have observed the empirical puzzle of 'inconsistent', 'positive', 'mixed' and 'conflicting' findings (Ruigrok \& Wagner 2004; Bausch \& Krist 2007; Verbeke et al. 2009), focusing on the shape of the relationship. Most of these empirical studies, however, have focused on large, well-internationalized firms, more than SMEs. Lin et al. (2011) 
argue that internationalisation negatively affects business performance, while Oviatt and McDougall (1994) and Brock and Yaffe (2008) observe no significant relationship. Dhanaraj and Beamish (2003) show a positive and direct linear link. $\mathrm{Lu}$ and Beamish (2006) show exporting contributes positively to SMEs' growth but negatively to their profitability. In some studies, a U-form relationship is clearly identified (Thomas 2006; Ruigrok \& Wagner 2003). Conversely Brock et al. (2006) and Jung and Bansal (2009) find an inverse U-form connection, while Lu and Beamish (2004), Thomas and Eden (2004), Ruigrok et al. (2007) and Vilas-Boas and Suàrez-Gonzàlez (2007) detect an S-form link. In addition, Contractor (2007) suggests a three-stage model where $U$, inverted-U and linear relationships depend on the degree of internationalisation.

According Ruigrok and Wagner (2004) and Bausch and Krist (2007), this divergence in the findings depends also on the specific internationalisation form and on how internationalisation and performance are measured. The main issue concerns the distinction among foreign direct investments (FDI) and exporting activities. Whilst FDI enable firms to benefit of location-based advantages by supporting the access to critical resources, competitively priced labor force and locally-embedded knowledge (Contractor et al., 2003), 'exporting provides SMEs with fast access to foreign markets, with little capital investment required, but the opportunity to gain valuable international experience' (Lu \& Beamish, 2001, p.568). Since SMEs typically face resource constraints which reduce FDI opportunities, this paper emphasizes internationalisation from an exporting perspective. In this perspective, exporting is expected to increase business performance by supporting larger volumes of sales and production, which enable firms to achieve economies of scale and improve labour productivity and management efficiency (Lu \& Beamish 2001, 2006).

\subsection{Learning perspective of internationalisation}

In order to gain a better understanding of the effect of internationalisation on performance, a number of moderating factors was introduced in the literature to explain this lack of findings convergence. Ruigrok and Wagner (2003) and Kotabe et al. (2002) suggested that existing research examining the internationalisation-performance link has overlooked potential moderating variables. Lin et al. (2011) show that moderating variables positively affect business performance. Glaum and Oesterle (2007) summarise the moderating effects of the firm's size, age, industry, product diversification, R\&D investments, country of origin and country of destination. Hsu and Pereira (2008) identify organisational learning as a critical moderator of the internationalisation- 
performance relationship in MNEs. The authors claim that 'the link between internationalisation and performance will be strengthened when firms engage in organisational learning activities' (Hsu \& Pereira 2008, p. 194). Similarly, Zahra and Hayton (2008) show the strength of the relationship between performance and international activities, such as acquisitions, alliances and corporate venture capital, is related to the level of firm's absorptive capacity.

Even though no conclusive empirical evidence concerning SMEs currently exists, the knowledge-based approach highlighted the key role of organisational learning in the internationalisation process. Learning orientation is critical to influence international behaviour of firms. Eriksson et al. (1997) stress the relevance to acquire specific knowledge about foreign markets to support the internationalisation process. Li et al. (2004) focus on experiential learning and systematic learning which are required to move from antecedents to the planning and execution of an internationalisation strategy. The internationalisation stage theories (Johanson \& Vahlne 1977, 2003; Cavusgil 1984; Barkema et al. 1997; Knight \& Liesch 2002) discuss the role of experiential learning on increasing international involvement and commitment. The experiential learning and new knowledge acquisition lead companies to continuously re-thinking their internationalisation, production and marketing strategies and developing products, processes and organisational routines, in order to better match the needs of the new markets. In this way, the company increases its competitiveness, reduces perceived risk and increases the availability of more resources to invest in that market or to explore new and different business opportunities that drive the company towards further market goals. In these models, the international evolution path depends on an increasing involvement and learning which leads to more challenging forms of internationalisation. However, even though the internationalisation stage theory suggests a positive relationship between highcontrol entry modes (foreign subsidiaries and joint ventures) and international learning (Zahra et al. 2000), the lack of financial and organisational resources to support foreign investments does not preclude SMEs the chance for global learning. According Lu and Beamish (2006, p. 30), 'exporting contributes to both firm growth and profitability indirectly by providing firms with an exposure to international markets and the concomitant opportunities to develop new knowledge about various markets'. Moreover, the network model emphasizes the need for development of market knowledge and the need to learn from interaction with other firms during the internationalisation process (Johanson \& Mattsson 1988). The exposure to and greater involvement with foreign customers and businesses in multiple markets is able to provide flexible access 
to locally embedded resources and knowledge (Yeoh 2004; Yang \& Driffield 2012). In this direction, Hennart (2007, p. 438) claims firms 'can and do learn outside from their network of affiliates, for example from international suppliers or customers'. Therefore, lower involved entry modes such as exporting, even though offer fewer opportunities for radical learning, enables firms to access to locally embedded assets by exploiting the relationships established with trusted foreign customers and distributors.

In addition, on the one hand, the resource-based perspective and the international entrepreneurship perspective respectively focus on the quality of organisational and human resources and competences (Ahokangas 1998) and on the role of management's ability (Oviatt \& McDougall 1994) as determinants of the exploitation learning, which is necessary to ensure the company's flexibility and capacity for adaptation. On the other hand, network perspective highlights the effect of extension of global networks on innovation and financial performances and stresses the role of social capital in driving firms learning opportunities to explore, acquire and assimilate external knowledge (Johanson \& Vahlne 2003; Jansson \& Sandberg 2008).

Finally, the successful internationalisation of SMEs is more probable when they are learning oriented because learning orientation enhances adaptation to foreign markets, access to external knowledge and network building with foreign customers and suppliers.

\section{Conceptual framework and hypotheses}

Based on our literature review, we propose a model in which internationalisation and learning play different roles in contributing to firms' financial performance. In particular, the path diagram model (Figure 1) highlights a direct effect between international commitment and financial performance and suggests an indirect effect as moderated by learning gained through international expansion.

First, even though the relationship between internationalisation and performance is not yet clear, following the dominant literature view, international involvement is expected to positively affect the business performance of SMEs. Specifically, exporting perspective suggests export activities are able to improve financial performance by increasing volume of sales and making possible to exploit scale economies, fostering risk reduction and improving flexible access to locally embedded resources and foreign markets knowledge. 


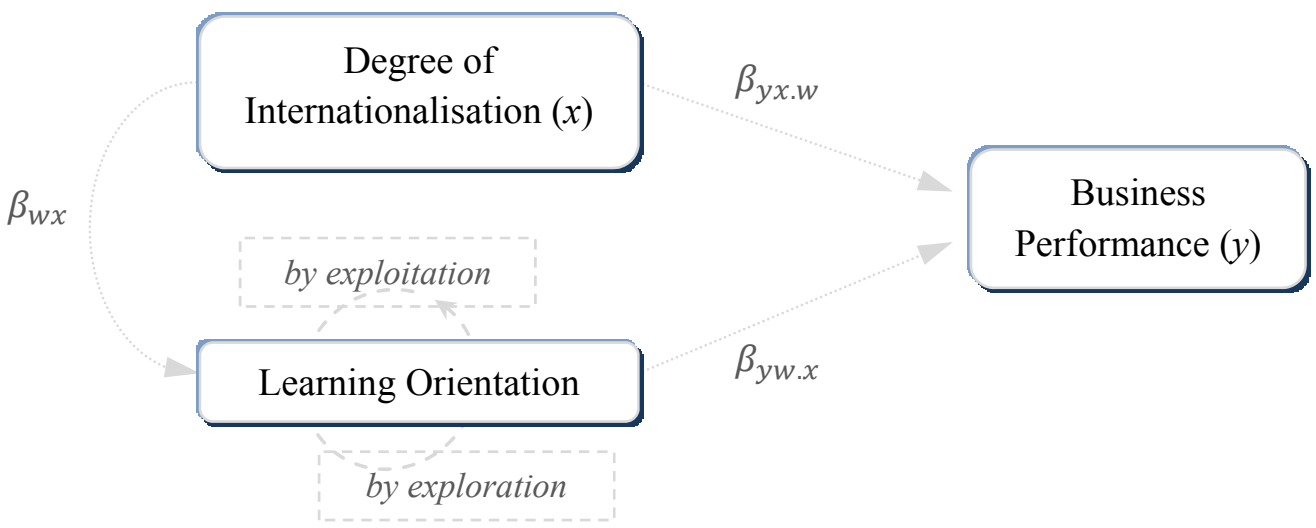

Figure 1. Path diagram model

Second, knowledge-based perspective of internationalisation advocates that international expansion is able to produce several opportunities for global learning. Most of the stage approaches to internationalisation of SMEs connects international expansion and learning ability (Johanson \& Vahlne 1977, 2003; Barkema et al. 1996; Cavusgil 1984). Lamb and Liesch (2002) define the path of internationalisation as a dynamic process of development and learning characterised by inherently uncertain outcomes. According to Eriksson et al. (2000), the experience accumulated in international markets represents a natural opportunity for organisational learning. Sharma and Blomstermo (2003) argue that internationalisation produces an evolution of skills, a renewal of organisational routines and, in general, a greater ability to manage business processes and knowledge. According to Jansson and Sandberg (2008), internationalisation allows a company to extend its relational network and in this way to facilitate access to collaboration, knowledge-sharing and resources and skills outside the system-enterprise. Contractor (2007) distinguishes two cognitive benefits produced by the internationalisation process. The first benefit is due to the internationalisation experience, which refers to organisational learning and improved ability to reproduce the firm in foreign locations. The second one concerns the ability to pick up on foreign knowledge as a result of the firm's international presence and the relationships the company is able to create and exploit in the foreign country. Thus, internationalisation enables firms to learn.

Finally, learning effort pertains to activities aimed at both building on existing knowledge and developing new knowledge (Cohen and Levinthal, 1990). March (1991) distinguishes these two activities as learning by exploitation and by exploration. According Noteboom (2004), exploitation refers to the efficient employment of current cognitive asset while exploration refers to its development. 
Based on these concerns, both exploitative and exploratory learning are defined and investigated to leverage the internationalisation-performance relationship.

On the one hand, the exploitative learning regards firms' ability to reorganise information, resources and knowledge within the organisation in order to support international adaptation and enhance business performance. Exploitative learning concerns knowledge application to increase the stock of knowledge available to the organisation (Grant 2008). It depends on the firm's interactive, acquisitive and absorptive capacities (March 1991), which are based on efficiency of organisational procedures such as strategic planning, best practices transfer, processes development, on-the-job training, communities of practices (Grant 2008). A greater firm's orientation to exploitative learning is expected to enhance business performance by supporting the improvement of organisational competences and routines and fostering a more effective adaptation to the foreign market.

Hypothesis 1 (H1). The relationship between internationalisation and business performance is positively moderated by the exploitative learning of firm.

On the other hand, the exploratory learning refers to firms' ability to research, collect and process external knowledge by exploiting international relationships with foreign customers, suppliers, institutions (Johanson \& Vahlne 2003). Exploratory learning enables firms to increase their amount of knowledge by acquiring new knowledge and new resources from outside sources (Grant \& Baden-Fuller 2004). Kim \& Atuahene-Gima (2010) define exploratory learning focusing on acquisition and use of market information to support products improvement and identify new needs and opportunities. Moreover, exploration aims to capture new development opportunities and stimulate the innovation process by leveraging relationships, collaborative partnerships and dynamic interaction, often with outsourcing or insourcing processes in relation to knowledge complexity (Lindsay et al. 2003). According Etemad and Lee (2003), companies may acquire the knowledge required for their foreign expansion by actively participating in extended global networks. Based on stronger exploratory learning, firms can more effectively leverage ties with other firms to capture opportunities for creating new products and services, targeting emerging market segments, creating new niches and meeting or even leading the needs of the emerging markets (Zahra1996; Li et al. 2014). Li et al. (2014) show exploratory learning concerns external resources acquisition (e.g. knowledge and technologies), products and skills development. It is further 
related to social capital resource types, such as ties with other firms and ties with government (Li et al. 2014). Firms with exploratory learning in alliances will likely benefit from their structural position in an open network (Yang et al. 2011). A greater firm's orientation to exploratory learning is expected to lead to higher economic and financial performance by supporting the development of collaborative relationships with international partners and the access to new resources and knowledge.

Hypothesis 2 (H2). The relationship between internationalisation and business performance is positively moderated by the exploratory learning of firm.

\section{Methodology}

Our methodological approach is based on path regression analysis. Path analysis (Welkowitz et al. 2006; Agresti \& Finlay 2008) is a statistical approach used to study the behaviour of variables within a relationship network. Its application requires the early definition of a full logical model (the path diagram is shown in Figure 1). In this study, path analysis is used to assess the moderating effect of learning orientation $(w)$ on the relationship between the degree of internationalisation $(x)$ and business performance $(y)$. Specifically a two-path model is applied, distinguishing between exploitative and exploratory learning. Each variable involved in the logical model has to be significantly linked to each other. However, path analysis requires some assumptions to be validated:

1. the simple effect $\left(\beta_{\mathrm{yx}}\right)$ between the principal variables $x$ and $y$ needs to be statistically significant;

2. the intermediary variable $w$ has to related to the dependent variable $y$ ( $\beta_{y w . x}$ has to be statistically significant);

3. the variable $x$ has to be related to the intermediary variable $w\left(\beta_{w x}\right.$ has to be statistically significant);

Operationally, once the assumptions are sound, the path model makes it possible to decompose the simple effect between the two main variables ( $x$ and $y$ ) into direct effect and mediated effect (by a third variable $w$ ), so that

$$
\beta_{y x}=\beta_{y x . w}+\beta_{y w . x} \cdot \beta_{w x}
$$

where $\beta_{\mathrm{yx}}$ is the simple effect, $\beta_{y x . w}$ is the direct effect and $\beta_{y w . x} \cdot \beta_{w x}$ represents the mediated effect. 
A value of direct effect lower than simple effect means the intermediary effect of the mediator variable is significant. Specifically, whether the direct effect is found to be not statistically significant, the mediated effect is full, otherwise it is partial.

\subsection{Data and sample}

Data were collected as part of Regional Repertoire of Excellent Enterprises Initiative, realised in 2007 by CNA Emilia Romagna._Data were based on two integrative questionnaires. The first one was a qualitative survey investigating exploitative and exploratory values affecting learning orientation. Multi-item scales are used and measured by 5-point Likert scales (ranging from 1='strongly disagree' to 5='strongly agree'). A confirmatory factor analysis was implemented to define both organisational learning constructs. Unidimensionality and reliability was further checked by using Cronbach's Alpha. The second questionnaire was a quantitative survey collecting firms' economic and financial indicators. It also involved data concerning firms' foreign sales.

The questionnaires were dispensed by CNA staff at the provincial level to management of companies involved in the project. In total, 311 complete and usable questionnaires were returned. Of these, over $90 \%$ were from micro and small $^{1}$ enterprises. A percentage of medium-sized enterprises was also selected to act as a control, to evaluate the effect of size on research objectives. The sampled SMEs are uniformly distributed among the provinces of the region. Minor differences are detectable. The most represented provinces are Modena (27\%), Ravenna (21\%) and Bologna (17\%). Consequently, most firms belong to the manufacturing industry sector (over $60 \%$ ), followed by construction $(17 \%)$ ). The industrial category "other" $(20.6 \%)$ comprises mainly the wholesale and retail trade $(9.6 \%)$ and financial assets $(7 \%)$.

Table 1 shows the descriptive statistics distinguishing between non-exporting and exporting firms (in the columns), and dimensional level, industry and province (in the rows). For exporting enterprises, the average level of exports relative to sales is shown too.

\footnotetext{
${ }^{1}$ European Union programmes or policies specifically define micro, small and medium-sized enterprises according to their employees' number and turnover. Micro firms employ fewer than 10 persons and turnover not exceed EUR 2 million, small firms employ fewer than 50 persons and turnover not exceed EUR 10 million, medium firms employ fewer than 250 persons and turnover not exceed EUR 43 million.
} 


\begin{tabular}{|c|c|c|c|c|c|c|}
\hline & \multirow[b]{2}{*}{$N$} & \multirow[b]{2}{*}{$\%$} & \multicolumn{2}{|c|}{ Non-Exporting Firms } & \multicolumn{2}{|c|}{ Exporting Firms } \\
\hline & & & $N$ & $\begin{array}{l}\% \text { (row conditional } \\
\text { frequency) }\end{array}$ & $N$ & $\begin{array}{l}\% \text { (row conditional } \\
\text { frequency) }\end{array}$ \\
\hline Total & 311 & $100.0 \%$ & 224 & $72.02 \%(72.02 \%)$ & 87 & $27.97 \%(27.97 \%)$ \\
\hline Micro & 131 & $42.1 \%$ & 104 & $33.44 \%(79.38 \%)$ & 27 & $8.68 \%(20.61 \%)$ \\
\hline Small & 167 & $53.7 \%$ & 114 & $36.65 \%(68.26 \%)$ & 53 & $17.04 \%(31.73 \%)$ \\
\hline Medium & 13 & $4.2 \%$ & 6 & $1.92 \%(46.15 \%)$ & 7 & $2.25 \%(53.84 \%)$ \\
\hline Manufacturing & 194 & $62.4 \%$ & 118 & $37.94 \%(60.82 \%)$ & 76 & $24.43 \%(39.17 \%)$ \\
\hline Construction & 53 & $17.0 \%$ & 46 & $14.79 \%(86.79 \%)$ & 7 & $2.25 \%(13.2 \%)$ \\
\hline Other & 64 & $20.6 \%$ & 60 & $19.29 \%(93.75 \%)$ & 4 & $1.28 \%(6.25 \%)$ \\
\hline Bologna & 55 & $17.7 \%$ & 34 & $10.93 \%(61.81 \%)$ & 21 & $6.75 \%(38.18 \%)$ \\
\hline Ferrara & 30 & $9.6 \%$ & 27 & $8.68 \%(90 \%)$ & 3 & $0.96 \%(10 \%)$ \\
\hline Forlì-Cesena & 31 & $10.0 \%$ & 16 & $5.14 \%(51.61 \%)$ & 15 & $4.82 \%(48.38 \%)$ \\
\hline Modena & 85 & $27.3 \%$ & 64 & $20.57 \%(75.29 \%)$ & 21 & $6.75 \%(24.7 \%)$ \\
\hline Parma & 19 & $6.1 \%$ & 17 & $5.46 \%(89.47 \%)$ & 2 & $0.64 \%(10.52 \%)$ \\
\hline Ravenna & 67 & $21.5 \%$ & 50 & $16.07 \%(74.62 \%)$ & 17 & $5.46 \%(25.37 \%)$ \\
\hline Reggio Emilia & 24 & $7.7 \%$ & 16 & $5.14 \%(66.66 \%)$ & 8 & $2.57 \%(33.33 \%)$ \\
\hline
\end{tabular}

Table 1. Global and domestic sample distributions for size, province and industry

\subsection{Variables}

In this section, the variables previously defined within the path regression model are specifically described.

\section{Business performance}

In economic literature, many financial ratios based on data of balance sheet are used to assess the economic sustainability of firms in terms of profitability, productivity, liquidity and financial structure. However, since Italian micro and small firms do not generally have an obligation to draw up a balance sheet, economic data of SMEs are often limited to the income statement. In this context, many of the financial indicators reported in the literature cannot be adopted in the our analysis (such as return on equity, return on assets and return on investment). Thus, a synthetic score was applied to combine all the relevant information for the assessment of corporate performance.

The scoring model was inspired by Altman's linear discriminant analysis model (Altman 1968). The model is based on a discriminant function that assigns a score to the sampled enterprises and is able to distinguish the top-performing companies from those under-performing. A multicollinearity analysis was applied to select the most suitable indices of performance. They result: added value per employee, 
profit margin on turnover, return on sales (ROS) and financial expenses (interest expenses on turnover).

$$
\text { Zscore }=a_{1} X_{1}+a_{2} X_{2}+a_{3} X_{3}+a_{4} X_{4}
$$

In this model, Zscore is the discriminant value calculated for each firm, $a_{i}$ refers to the discrimination coefficients and $X_{i}$ refers to the performance variables selected. The estimate of coefficients $a_{i}$ is achieved through a logit regression model. The model uses a dummy dependent variable where the value 1 represents the performing companies and the value 0 the under-performing ones. The distinction between "performing" and "under-performing" is formulated on the basis of a non-hierarchical cluster analysis (function pam of the cluster package of statistical program R), which simultaneously considers all the performance indicators selected.

\section{Exploitative and exploratory learning}

Since the complexity of learning construct makes difficult to measure the effective learning ability of firms, we specifically focus on exploitative and exploratory values able to affect learning orientation of firms.

Exploitative and exploratory learning are respectively measured using two set of items (as reproduced in the Appendix A). Items are elaborated from literature (Grant 2008; Kim \& Atuahene-Gima 2010; Li et al. 2014). Based on resourcebased and knowledge-based perspective, the former set involves management capabilities to define, plan and communicate strategic and production goals, to support a collaborative environment for supporting internal knowledge sharing, transfer and learning.

The latter set, based on network perspective, includes items concerning the relationship with suppliers and customers and their involvement, the outsourcing partnership, the strategic ability to look for external knowledge (R\&D and technology strategy) and for monitoring the market.

A confirmatory factor model (Grice 2001) is then applied to identify the latent factors underlying the two respective sets of items in order to summarise the ability to learn by exploration and exploitation for each company. The internal consistency of the two groups of items has been validated by measuring Cronbach's Alpha. Since the literature is unanimous in adopting a value of 0.70 as a reference to a barely acceptable level of internal consistency and the appropriateness of the constructed test (Nunnally 1978; Hair et al. 1995), the values of 0.76 for the first group and 0.78 for the second one confirm the soundness of the constructs. In Appendix A, Table 4 shows that the standardised loadings of factor analysis are over 0.40 . 


\section{Degree of internationalisation}

To measure the level of internationalisation of SMEs, almost all the authors suggest adopting as an indicator foreign sales as a percentage of total sales (Stopford \& Wells 1972). According internationalisation stage theory, exporting is traditionally the main form to access foreign markets (Ramaswamy et al. 1996; Leonidou \& Katsikeas 1996; Majocchi \& Zucchella 2003) and progressively leads to more challenging modes of internationalisation (Johanson \& Vahlne 1977, 2003). However, this international development requires increasing resources and investments, which are often precluded to SMEs. Moreover, FDI activities are complementary and not substitutive of export activities (Basile et al. 2003). The hypothesis of substitution between exports and horizontal investment does not occur or occurs only partially (Head \& Ries 2004). Indeed, in many cases, the main route into a foreign market and the increasing penetration of the brand that goes with it can act as driving force for a company's other products, increasing rather than reducing the flow of exports (Castellani \& Zanfei 2007). Thus, we retain the ratio of foreign sales on total turnover is to be considered a good proxy of SMEs' international involvement and commitment.

\section{Control variables}

Different control variables are included to ensure the adaptive capacity of multivariate regression models. First, larger firms are expected to have higher business performance because their availability or accessibility to higher levels of resources (Barkema et al. 1996; Zahra et al. 2000; Yeoh 2004). Size is here defined according to the number of employees. Second, we also control for company age since several studies suggest it can influence the level of learning and international performance (Oviatt and McDougall 1994; Zahra et al. 2000). Finally, provinces and industries in which firms operate are also considered to control for geographical and industrial effects.

\subsection{Results of analysis}

In Table 2, descriptive statistics and correlation matrix are reported. The data concerning internationalised firms are in brackets. A one-way analysis of variance (Anova test) on average values is further introduced to assess the presence of significant difference between domestic and global firms. 


\begin{tabular}{|c|c|c|c|c|c|c|c|c|c|}
\hline Variables & $\underset{(I)}{M e a n}$ & $\underset{(I)}{S t}$ dev. & $\begin{array}{l}\text { Anova } \\
\text { test }\end{array}$ & 1 & 2 & 3 & 4 & 5 & 6 \\
\hline $\begin{array}{l}\text { 1. Business } \\
\text { performance } \\
\text { (Z-score) }\end{array}$ & $\begin{array}{l}13.90 \\
(14.54)\end{array}$ & $\begin{array}{l}1.083 \\
(1.081)\end{array}$ & $21.4^{* * *}$ & $\begin{array}{l}1 \\
(1)\end{array}$ & & & & & \\
\hline 2. Size of Firm & $\begin{array}{l}14.20 \\
(22.39)\end{array}$ & $\begin{array}{l}15.94 \\
(19.49)\end{array}$ & $14.1^{* * *}$ & $\begin{array}{l}0.52 \\
(0.74)\end{array}$ & $\begin{array}{l}1 \\
(1)\end{array}$ & & & & \\
\hline 3. Age of Firm & $\begin{array}{l}19.63 \\
(19.28)\end{array}$ & $\begin{array}{l}14.11 \\
(13.07)\end{array}$ & 0.03 & $\begin{array}{l}0.18 \\
(0.04)\end{array}$ & $\begin{array}{l}0.07 \\
(-0.04)\end{array}$ & $\begin{array}{l}1 \\
(1)\end{array}$ & & & \\
\hline $\begin{array}{l}\text { 4. Exploitative } \\
\text { learning }\end{array}$ & $\begin{array}{l}-0.080 \\
(0.173)\end{array}$ & $\begin{array}{l}1.009 \\
(0.676)\end{array}$ & $4.67 *$ & $\begin{array}{l}0.46 \\
(0.29)\end{array}$ & $\begin{array}{l}0.29 \\
(0.28)\end{array}$ & $\begin{array}{l}0.06 \\
(-0.15)\end{array}$ & $\begin{array}{l}1 \\
(1)\end{array}$ & & \\
\hline $\begin{array}{l}\text { 5. Exploratory } \\
\text { learning }\end{array}$ & $\begin{array}{l}-0.096 \\
(0.252)\end{array}$ & $\begin{array}{l}0.803 \\
(0.825)\end{array}$ & $11.3 * * *$ & $\begin{array}{l}0.31 \\
(0.46)\end{array}$ & $\begin{array}{l}0.30 \\
(0.46)\end{array}$ & $\begin{array}{l}-0.00 \\
(-0.13)\end{array}$ & $\begin{array}{l}0.47 \\
(0.63)\end{array}$ & $\begin{array}{l}1 \\
(1)\end{array}$ & \\
\hline 6. Foreign sales & $\begin{array}{l}- \\
(0.197)\end{array}$ & $\begin{array}{l}- \\
(0.253)\end{array}$ & - & $\begin{array}{l}- \\
(0.49)\end{array}$ & $\begin{array}{l}- \\
(0.38)\end{array}$ & $\begin{array}{l}- \\
(0.02)\end{array}$ & $\begin{array}{l}- \\
(0.17)\end{array}$ & $\begin{array}{l}- \\
(0.18)\end{array}$ & $\begin{array}{l}- \\
(1)\end{array}$ \\
\hline
\end{tabular}

${ }^{(1)}$ Domestic firms values are out of brackets, while internationalised firms values are in brackets.

${ }^{(2)} F$-test and significant level is reported

Significant levels are 0 '***’ 0.001 '**’ 0.01 '*’ 0.05 ‘’ 0.1 ' ’ 1
}

Table 2. Descriptive statistics and correlation matrix for domestic and global firms.

Descriptive statistics show that business performance, size, exploitation and exploration are significantly higher in internationalised than in domestic firms. Age of firms makes no difference.

The correlation matrix shows that size is related to performance for both domestic $(r=.52)$ and exporting firms $(r=.74)$. Conversely, the correlation between age and performance is relatively low, especially for firms operating in foreign markets $(r=.04)$. Exploitative and exploratory learning are both positively related to business performance. However, correlation weights are inverted; exploitation $(r=.46)$ is higher than exploration $(r=.31)$ in the domestic sample, while exploration $(r=.40)$ is higher than exploitation $(r=.29)$ in the internationalised sample. International involvement is also positively related to performance $(r=.49)$.

The first step of the analytical research is to verify the path model assumptions, to see whether both the learning and intensity of exports are statistically significant predictors of business performance. Two sets of hierarchical regression models are built (Table 3) and business performance is used as a dependent variable. Data outliers by measuring Cook's distance ${ }^{2}$, are deleted because they may distort the outcome and accuracy of regression model. The robustness of regression models is verified by measuring $\mathrm{R}^{2}$, adjusted $\mathrm{R}^{2}$ and the F-stat. The coefficients are

\footnotetext{
${ }^{2}$ Specifically, two internationalized firms are excluded because of financial performance much higher than sample's average.
} 
standardised to foster the reading of analysis results. Multicollinearity effects are excluded by measuring the variance inflation factor (VIF test). The highest VIF, occurring in model 7 (VIF max equal to 1.86), lower than the cut-off point of 10 (Aiken \& West 1991), reveals a negligible multicollinearity effect among the variables.

The first set of models concerns only the enterprises operating on the domestic market while the second set concerns only internationalised companies. This distinction is necessary because learning orientation may affect both local and global firms, while export activities concern only the latter. The soundness of the model is ensured by including some control variables, such as firm size, firm age, industry and province. Size is always relevant within local and global context; age is more significant for domestic than global firms; industry and province effects are not emphasised.

\begin{tabular}{|c|c|c|c|c|c|c|c|}
\hline \multirow[b]{3}{*}{ Variables } & \multicolumn{3}{|c|}{ Non-Exporting Firms } & \multicolumn{4}{|c|}{ Exporting Firms } \\
\hline & \multicolumn{3}{|c|}{$\begin{array}{c}\text { V.D. Business Performance } \\
\text { (Zscore) }\end{array}$} & \multicolumn{4}{|c|}{ V.D. Business Performance (Zscore) } \\
\hline & Model 1 & Model 2 & Model 3 & Model 4 & Model 5 & Model 6 & Model 7 \\
\hline Intercept & $\begin{array}{l}0.002 \\
(0.056)\end{array}$ & $\begin{array}{l}0.015 \\
(0.059)\end{array}$ & $\begin{array}{l}0.003 \\
(0.057)\end{array}$ & $\begin{array}{l}0.007 \\
(0.065)\end{array}$ & $\begin{array}{l}0.009 \\
(0.065)\end{array}$ & $\begin{array}{l}0.009 \\
(0.063)\end{array}$ & $\begin{array}{l}0.004 \\
(0.063)\end{array}$ \\
\hline Size & $\begin{array}{l}0.459 \\
(0.062)^{* * *}\end{array}$ & $\begin{array}{l}0.521 \\
(0.063)^{* * *}\end{array}$ & $\begin{array}{l}0.454 \\
(0.063)^{* * *}\end{array}$ & $\begin{array}{l}0.755 \\
(0.068)^{* * *}\end{array}$ & $\begin{array}{l}0.743 \\
(0.073)^{* * *}\end{array}$ & $\begin{array}{l}0.678 \\
(0.072)^{* * *}\end{array}$ & $\begin{array}{l}0.689 \\
(0.072)^{* * *}\end{array}$ \\
\hline Age & $\begin{array}{l}0.142 \\
(0.057)^{*}\end{array}$ & $\begin{array}{l}0.158 \\
(0.060)^{* *}\end{array}$ & $\begin{array}{l}0.144 \\
(0.057)^{*}\end{array}$ & $\begin{array}{l}0.097 \\
(0.069)\end{array}$ & $\begin{array}{l}0.102 \\
(0.066)\end{array}$ & $\begin{array}{l}0.122 \\
(0.063) \dagger\end{array}$ & $\begin{array}{l}0.114 \\
(0.063) \dagger\end{array}$ \\
\hline Province & Yes & Yes & Yes & Yes & Yes & Yes & Yes \\
\hline Industry & Yes & Yes & Yes & Yes & Yes & Yes & Yes \\
\hline $\begin{array}{l}\text { Exploitative } \\
\text { learning }\end{array}$ & $\begin{array}{l}0.304 \\
(0.061)^{* * *}\end{array}$ & - & $\begin{array}{l}0.286 \\
(0.068)^{* * *}\end{array}$ & - & $\begin{array}{l}0.033 \\
(0.070)\end{array}$ & - & $\begin{array}{l}-0.096 \\
(0.082)\end{array}$ \\
\hline $\begin{array}{l}\text { Exploratory } \\
\text { learning }\end{array}$ & - & $\begin{array}{l}0.153 \\
(0.060)^{*}\end{array}$ & $\begin{array}{l}0.039 \\
(0.064)\end{array}$ & - & - & $\begin{array}{l}0.187 \\
(0.072)^{*}\end{array}$ & $\begin{array}{l}0.246 \\
(0.088)^{* *}\end{array}$ \\
\hline $\begin{array}{l}\text { Foreign } \\
\text { sales }\end{array}$ & - & - & - & $\begin{array}{l}0.403 \\
(0.121)^{* *}\end{array}$ & $\begin{array}{l}0.399 \\
(0.121)^{* *}\end{array}$ & $\begin{array}{l}0.406 \\
(0.115)^{* * *}\end{array}$ & $\begin{array}{l}0.417 \\
(0.116)^{* * *}\end{array}$ \\
\hline $\mathrm{R}^{2}$ & 0.421 & 0.365 & 0.424 & 0.734 & 0.735 & 0.759 & 0.764 \\
\hline Adj. $\mathrm{R}^{2}$ & 0.411 & 0.354 & 0.410 & 0.722 & 0.719 & 0.744 & 0.745 \\
\hline VIF max & 1.140 & 1.087 & 1.391 & 1.139 & 1.301 & 1.375 & 1.861 \\
\hline Test $\mathrm{F}$ & $43.2 * * *$ & $34.1 * * *$ & $32.3^{* * *}$ & $60.84 * * *$ & $45.15^{* * *}$ & $51.17 * * *$ & $41.47 * * *$ \\
\hline
\end{tabular}

Table 3. Hierarchical regression models to test assumptions of path analysis 
In the models concerning domestic firms, both exploitative and exploratory learning are significantly positive when they are individually introduced (models 1 and 2). However, exploratory learning becomes irrelevant when compared to exploitative one in model 3.

The second set of regression models focuses on global firms. Exporting intensity is introduced to assess the degree of international involvement. The findings are very different compared to previous models. Firstly, the significant and positive coefficient of export within all models supports the first assumption $\beta_{y x}$ (exporting affects business performance) of path regression model. Second, the role of exploitative and exploratory learning is reversed for firms moving to foreign market compared to firms operating into domestic market. Specifically, exploratory learning is significant and positive in both model 6 and 7, while the exploitative learning effect on business performance is inconsistent even if separately included (model 5). Thus, the second assumption $\beta_{y w . x}$ of path model (learning significantly influences business performance) is only confirmed for exploratory learning. Conversely, even though the average level of exploitative learning is higher for global firms than domestic one (as suggested by Anova test in Table 2), exploitative learning does not significantly leverage the internationalisation-performance relationship. Therefore, the lack in second assumption (for exploitative learning) makes hypothesis $H 1$ unsupported.

A regression model is further applied to independently test the effect of international expansion on exploratory learning (the beta coefficient is 0.131 and the significance level is less than 0.05). The outcome validates the third assumption; $\beta_{y w . x}$ is statistically significant and positive.

Finally, the simple effects among internationalisation, exploratory learning and business performance are recomputed without control variables in order to implement the path regression model. The coefficient weights and the respective statistical significances are shown in the path diagram (Figure 2).

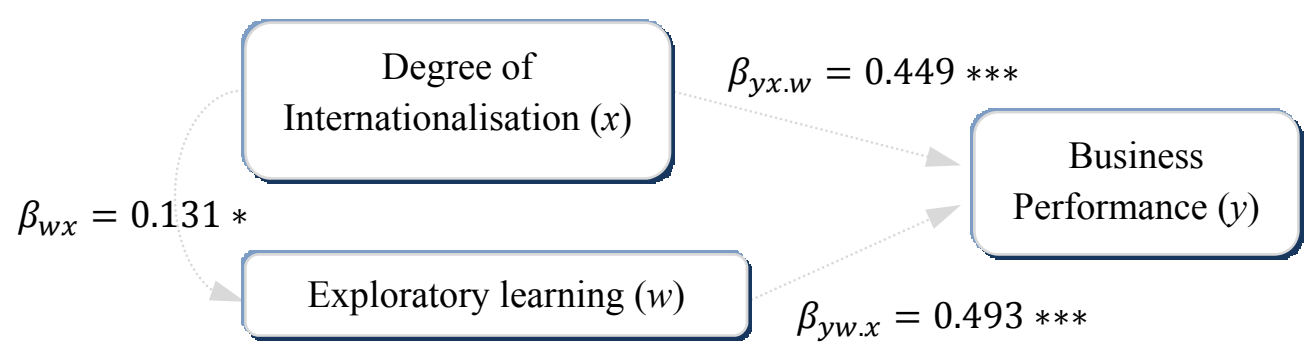

Figure 2. Path analysis diagram with resultant coefficients 
The simple effect between predictor (degree of internationalisation) and dependent variable (business performance) matches the sum of direct effect (between the same variables) and mediated effect (by learning capacity), so that:

$$
\beta_{y x}=\beta_{y x . w}+\beta_{y w . x} \cdot \beta_{w x}=0.4491+0.4934 \cdot 0.1313=0.514
$$

In conclusion, the exploratory learning stimulating by internationalisation process partially affects the business performance. Since most of simple effect is due to direct effect, we can claim that internationalisation involvement is a critical driver of firms' financial performance. However, the ability to create new international relationships and to acquire new knowledge can further increase the effect of the internationalisation process. Thus, hypothesis $H 2$ is to be supported.

\section{Discussion}

The evidence proves that a positive relationship between exporting activities of SMEs and business performance can be discerned. In addition, the process of internationalisation can further improve economic performance by increasing the level of exploratory learning. In other words, the moderating effect of exploratory learning makes international expansion even more profitable. Conversely, the exploitative learning process does not seem to affect business performance by leveraging the internationalisation process.

Specifically, the research findings show that exploitative learning affects business performance in a local rather than in a global context and that international firms statistically have higher average performance than domestic ones (as confirmed by Anova test in Table 2). This may validate the thesis of scholars suggesting that organisational ability to leverage and develop internal resources, processes, routines and skills is a relevant antecedent for moving into foreign markets (Hasan \& Raturi 2003; Harris \& Li 2009). In this concerning, the decision for moving to foreign markets is usually based on the starting stock of knowledge, which in turn depends on the company's specific competencies and experiences (Eriksson et al. 2000) and the routines developed in domestic markets are critical to fostering the learning process required for firms' expansion abroad (Barkema et al. 1996). Therefore, exploitative learning is probable to enable firms to internationalisation but it does not significantly increase due to international expansion. However, since this finding is limited to exporting perspective, a higher international commitment leading to different global expansion modes (such as FDI) likely requires an increasing organisational development, which further depends on exploitative learning. 
In this context, policy makers have to stimulate initiatives that reduce attitudinal, resource, operational and strategic barriers in order to better support both entry mode and development path of SMEs' internationalisation. In early internationalisation, entrepreneurs have to consider the skills and resources they need to sustain their internationalisation activity because the lack of skilled personnel, of effective organisational routines and of adequate stock of knowledge can preclude firms from successfully moving into foreign markets. For example, many firms choose to take on management staff with a particular international profile and experience from other companies in order to acquire tacit knowledge and competencies to develop internationalisation process (Eriksson et al. 2000; Casillas et al. 2010). Thus, the first task of regional institutions is to train entrepreneurs on the antecedents, benefits, disadvantages and costs of internationalisation process. Not every firm benefits from global growth. The liabilities relating to 'newness', 'smallness' and 'inexperience' tend often to influence internationalisation propensity and strategy of SMEs (Wright et al. 2007). In some cases, it is more beneficial for a firm to withdraw from internationalisation and focus on the domestic market. SMEs oriented to international markets require identifying their competitive advantages such as branding, marketing, technology development, financing or other managerial and organisational capabilities (Pangarkar 2008). Internationalisation intention recommends a careful evaluation of trade-off between benefits and costs.

Moreover, since internationalisation expansion requires specific knowledge that new global firms may find difficult to locate and acquire, policy makers should encourage and support firms to access external pools of resources and opportunities, through the development of networks and cooperative arrangements with foreign customers and suppliers. Presutti et al. (2011) argue that major foreign customers are able to sustain knowledge acquisition by fostering introductions to other customers and to their knowledge bases. Since international customers and suppliers are the most suitable sources of knowledge because of their awareness of the foreign market, social interactions and cooperation enable firms to acquire more market information, to develop products and processes, and define specific target strategy (Kim \& Atuahene-Gima 2010).

Therefore, the exploratory learning gained from internationalisation may be useful for marketing strategies by enhancing the firm's ability to improve the market knowledge, to better satisfy foreign customers' needs, and to create opportunities for moving to other foreign markets. Exploratory learning enables firms to globally mature by strengthening brand reputation, developing new products and 
technologies, creating new relationships and producing new opportunities for growth (Atuahene-Gima \& Murray 2007).

Finally, since the importance of being directly operative in global markets in order to better exploit learning opportunities, the role of indirect exporting needs to be adequately weighted. Indirect exporting reduces firms' involvement and financial risks but does not produce knowledge benefits and relational improvements. Thus, while the regional promotion of incubators or consortia to support the exporting performance of SMEs is functional over a limited period of time, the international market presence is necessary to activate learning processes and to foster global expansion.

In this direction, regional building policies should provide a proactive platform for internationalisation of local SMEs developing formal and informal mechanism of control to avoid opportunistic behaviours, by increasing trust, credibility and motivation to knowledge sharing and social interaction. Providing a context in which knowledge transfers can be more effective (West \& Noel 2009), based on cognitive and social proximity among partners more than geographical proximity (Presutti et al. 2011), may be further crucial. The development of international trustful networks can foster knowledge transfer and sharing, mutual support, product and process innovation and improvement, which positively affects firms' competitiveness and internationalisation dynamics (Acs et al. 1997). Enlarged global network involving foreign customers and suppliers may support firms to enhance exploratory learning and to provide the conditions for cooperative innovation.

\section{Conclusion}

This study offers a theoretical framework and empirical assessments to the investigating of the relationship between internationalisation, organisational learning and performance. Two different kinds of learning were identified. The moderating role of exploitative and exploratory learning on internationalizationperformance link is developed and tested. This study contributes to the developing trend in international business research to explain the internationalisation process of SMEs in terms of learning and its effect on business performances.

Even though the traditional internationalization stage theories involves an evolutionary path where the moving from each stage continually requires an increasing amount of resources and learning, the findings highlight the role of exploratory learning more than exploitative one. Specifically the analysis shows that, on the one hand, SMEs need to antecedently develop and exploit their existing organisational resources and competences to successfully moving to 
foreign markets, while, on the other hand, knowledge accumulation and exploratory learning capacity are crucial to foster the international expansion and positively affect business performances. Therefore, the development of social international relationships with customers, suppliers, partners and institutions is able to foster internationalisation process by supporting the access to external knowledge, improving the understanding and awareness of foreign markets features and evolution and exploring new expansion opportunities.

In conclusion, some inherent limitations and further researches are to be considered and suggested. First, there are a number of concerns surrounding the size and representativeness of sample which might have local-specific advantages, or technological and managerial know-how. It may be useful to replicate this study with a larger sample representing the whole Italian context or additionally enlarged to European countries. Second, some concerns regard the general validity of measures operationalized in the study, such as the range of constructs we developed to indicate exploitative and exploratory learning. Establishing a more sophisticate, accurate and reliable instrument that captures the multiple facets of organisational learning is considered to be a crucial aspect for future research. Similarly, Glaum and Oesterle (2007) have already highlighted the problems relative to the internationalisation and business performance measurements. Finally, longitudinal data might be useful to determine whether as the effect of learning changes over time.

Acknowledgements. The authors would like to thank the editor and three anonymous reviewers for their constructive and invaluable comments and suggestions during the review process. They would also like to thank the management and the staff of CNA Emilia Romagna for being exceptionally collaborative in providing data and support this research study. We further thank Cristina Mateo Lobato for helpful comments and Spanish translation support.

Ethical Statement. The authors declare the research was conducted in accord with prevailing ethical principles.

Conflict of Interest. The authors declare that they have no conflict of interest.

\section{References}

Acs, Z. J., Morck, R., Shaver, J. M., Yeung, B. (1997). The internationalization of small and medium-sized enterprises: a policy perspective. Small Business Economics, 9(1), 7-20. 
Agresti, A., Finlay, B. (2008). Statistical Methods for the Social Sciences, 4th edition, Pearson Prentice Hall.

Ahokangas, P. (1998). Internationalisation and resources: an analysis of processes in Nordic SMEs. Universitas Wasaensis, Vaasa.

Aiken, L. S., West, S. G. (1991). Multiple regression: Testing and interpreting interactions. Newbury Park, CA: Sage.

Altman, E. I. (1968). Financial ratios, discriminant analysis, and the prediction of corporate bankruptcy. Journal of Finance 23, 589-609.

Atuahene-Gima, K., \& Murray, J. Y. (2007). Exploratory and exploitative learning in new product development: A social capital perspective on new technology ventures in China. Journal of International Marketing, 15(2): 1-29.

Barkema, H.G., Bell, J.H.J. and Pennings, J.M. (1996). Foreign entry, cultural barriers, and learning. Strategic Management Journal, 17(2), 151-76.

Barkema, HG, Shenkar, O, Vermeulen, F, Bell, JHJ. (1997). Working abroad, working with others: how firms learn to operate international joint ventures. Academy of Management Journal, 40, 426-442.

Basile, R., Giunta, A., Nugent, J.B. (2003). Foreign Expansion by Italian Manufacturing Firms in the Nineties: an Ordered Probit Analysis. Review of Industrial Organization, 23, 1-24.

Bausch, A., Krist, M. (2007). The effect of context-related moderators on the internationalization-performance relationship: Evidence from meta-analysis. Management International Review, 47(3), 319-347.

Brock D.M., Yaffe T., (2008). International Diversification and Performance: the Mediating Role of Implementation, International Business Review, 17, 600-15.

Brock, D.M. , Yaffe, T. , Dembovsky, M. (2006). International Diversification and Performance: A Study of Global Law Firms. Journal of International Management

Capar, N., Kotabe, M. (2003). The relationship between international diversification and performance in service firms. Journal of International Business Studies, 34(4), 345-355.

Casillas, J. C., Moreno, A. M., Acedo, F. J., Gallego, M. A., Ramos, E. (2009). An integrative model of the role of knowledge in the internationalization process. Journal of World Business, 44(3), 311-322. 
Castellani, D., Zanfei, A. (2007). Internationalisation, Innovation and Productivity: how do firms differ in Italy?. The World Economy, 30(1), 156176.

Cavusgil ,S.T. (1984). Differences among Exporting Firm Based on their Degree of Internationalization. Journal of Business Research, 12, 195-208.

Conner, K. R., Prahalad, C. K. (1996). A Resource-Based Theory of the Firm: Knowledge versus Opportunism. Organization Science, 7 (5), 477-501.

Contractor, F. J. (2007). Is international business good for companies? The evolutionary or multi-stage theory of internationalization vs. the transaction cost perspective. Management International Review, 47(3), 453-475.

Contractor, F.J., Kundu, S., Hsu, C.C. (2003). A three stage theory of international expansion: the link between multinationality and performance in service sector. Journal of International Business, 34(1), 5-18.

Dhanaraj, C., Beamish, P.W. (2003). A Resource-Based Approach to the Study of Export Performance. Journal of Small Business Management, 41 (3), 242-61.

Dunning, J. H. (1981). International Production and the Multinational Enterprise. George Allen \& Unwin, London.

Eriksson, K., Johanson, J., Majkgård, A., Sharma, D. D. (1997). Experiential knowledge and cost in the internationalization process, Journal of International Business Studies 28 (2), 337-360.

Eriksson, K., Johanson, J., Majkgård, A., Sharma, D. D. (2000). Effect of variation on knowledge accumulation in the internationalization process. International Studies of Management \& Organization, 30(1), 26-44.

Etemad, H., Lee, Y. (2003). The knowledge network of international entrepreneurship: Theory and evidence. Small Business Economics, 20(1), 523.

Glaum, M., Oesterle, M. J. (2007). 40 years of research on internationalization and firm performance: more questions than answers?. Management International Review, 47(3), 307-317.

Grant, R.M. (2008). Contemporary Strategy Analysis. Oxford: Blackwell Publishing Ltd, $6^{\text {th }}$ ed.

Grant, R.M., Baden-Fuller, C. (2004). A knowledge accessing theory of strategic alliances, Journal of Management Studies, 41, 61-84. 
Grice, J.W. (2001). Computing and evaluating factor scores. Psychological Methods, 6, 430-450

Harris, R., Li, Q.C. (2009). Exporting, R\&D and absorptive capacity in UK establishments, Oxford Economic Papers, 61, 74-103.

Hasan, R., Raturi, M. (2003). Does Investing in Technology Aspects Exports: Evidence on Indian Firms, Review of Development Economics, 7, 279-293.

Head, K,. Ries, J. (2004). Exporting and FDI as alternative strategies, Oxford Review of Economic Policy,20, 409-23.

Hennart, J. F. (2007). The theoretical rationale for a multinationality-performance relationship. Management International Review, 47(3), 423-452.

Hsu, C.C., Pereira, A. (2008). Internationalization and performance: The moderating effects of organizational learning, International Journal of Management Science, 36, 188 - 205.

Hymer, S. (1976). The international operations of national firms: A study of direct foreign investment. MIT press, Cambridge, MA.

Jansson H., Sandberg S., (2008). Internationalization of small and medium sized enterprises in the Baltic Sea Region, Journal of International Management, $14(1), 65-77$.

Johanson, J., Mattsson, G. (1988). Internationalization in industrial systems - a network approach. In Hood N. \& Vahlne J.E (ed.), Strategies in Global Competition, Stockholm School of Economics, New York: Croom Helm, pp. 287-314

Johanson, J., Vahlne, J.E. (1977). The internationalization process of the firm: a model of knowledge development and increasing foreign market commitments, Journal of International Business Studies, 8(2), 23-32.

Johanson, J., Vahlne, J.E. (2003). Business relationship learning and commitment in the internationalization process, Journal of International Enterpreneurship, $1,83-101$.

Jung, J.C., Bansal, P. (2009). How Firm Performance affects Internationalization, Management International Review, 49(6), 709-732

Kim, N., \& Atuahene-Gima, K. (2010). Using Exploratory and Exploitative Market Learning for New Product Development. Journal of Product Innovation Management, 27(4), 519-536. 
Knight, G., Liesch, P. (2002). Information internalisation in internationalising the firm, Journal of Business Research, 55(12), 981-95.

Kogut, B., Zander, U. (1992). Knowledge of the Firms, Combinative Capabilities, and the Replication of Technology, Organization Science, 3 (3), 383-397.

Lamb, P.W., Liesch, P.W. (2002). The Internationalization Process of the Smaller Firm: Re-framing the Relationships between Market Commitment, Knowledge and Involvement, Management International Review, 42(1), 7-26.

Leonidou, L.C., Katsikeas, C. S. (1996). The export development process: An integrative review of empirical models. Journal of International Business Studies, 27(3), 517-551.

Li, L., Li, D., Dalgic, T. (2004). Internationalization process of small and medium-sized enterprises: Toward a hybrid model of experiential learning and planning. Management International Review, 44(1), 93-116.

Li, Y., Chen, H., Liu, Y., \& Peng, M. W. (2014). Managerial ties, organizational learning, and opportunity capture: A social capital perspective. Asia Pacific Journal of Management, 31(1), 271-291.

Lin, W.T., Liu, Y., Cheng, K.Y. (2011). The Internationalization and Performance of a Firm: Moderating Effect of a Firm's Behavior, Journal of International Management, 17(1), 83-95.

Lindsay, V., Chadee, D., Mattsson, J., Johnston, R., Millett, B. (2003). Relationships, the role of individuals and knowledge flows in the internationalisation of service firms. International Journal of Service Industry Management, 14(1), 7-35.

Lu, J.W., Beamish, P.W. (2006). Partnering strategies and performance of SMEs' international joint ventures. Journal of Business Venturing, 21(4), 461-486.

Lu, J.W., Beamish, P.W. (2001). The Internationalization and Performance of SMEs, Strategic Management Journal, 22(6-7), 565-586.

Lu, J.W., Beamish, P.W., (2004). International Diversification and Firm Performance: S-Curve Hypothesis, Academy of Management Journal, 47(4), 598-609.

Majocchi, A., Zucchella, A. (2003). Internationalisation and performance, findings from a set of Italian SMEs. International Small Business Journal, 21, 249-268. 
March, J.G. (1991). Exploration and exploitation in organizational learning. Organization Science, 10 (1), 299-316.

Nickerson, J.A., Zenger, T. (2004). A Knowledge-Based Theory of Governance Choice: The Problem-Solving Approach, Organization Science, 15, 617-632.

Nunnally, J.C. (1978). Psychometric Theory. New York, NY: McGraw-Hill.

Oviatt, B. M., McDougall, P. P. (1994). Toward a theory of international new ventures, Journal of International Business Studies, 25(1), 45-64.

Pangarkar, N. (2008). Internationalization and performance of small-and mediumsized enterprises. Journal of World Business, 43(4), 475-485.

Prahalad, C. K., Hamel, G. (1990). The core competence of the corporation. In Zack, M. H. (eds.). Knowledge and strategy. Butterworth-Heinemann, Woburn, MA, p. 41-63.

Presutti, M., Boari, C., Majocchi, A. (2011). The Importance of Proximity for the Start-Ups' Knowledge Acquisition and Exploitation. Journal of Small Business Management, 49(3), 361-389

Ramaswamy, K., Kroeck, K. G., Renforth, W. (1996). Measuring the degree of internationalisation of a firm: A comment. Journal of International Business Studies, 27(1), 167-177.

Ruigrok W, Wagner H., (2003). Internationalization and performance: an organizational learning perspective. Management International Review, 43(1):63-83.

Ruigrok W., Amann W., Wagner H., (2007). The InternationalizationPerformance Relationship at Swiss Firms: A Test of the S-shape and Extreme Degrees of Internationalization, Management International Review, 47,349-68.

Sharma D.D., Blomstermo A., (2003), The internationalization process of born globals: a network view, International Business Review, 12, 739-753.

Stopford J., Wells L.T., (1972), Managing the Multinational Enterprise: Organization of the Firm and Ownership of Subsidiaries, New York: Basic Books.

Teece, D. J. (1983). Technological and organizational factors in the theory of the multinational enterprise. In Casson M. (eds.) The growth of international business, Allen and Unwin, London, p. 51-62. 
Thomas D., Eden L. (2004). What is the Shape of the MultinationalityPerformance Relationship?, Multinational Business Review, 12(1): 89-110.

Thomas D.E., (2006). International Diversification and Firm Performance in Mexican Firms: A curvilinear Relationship?, Journal of Business Research, 59(4): 501-507.

Verbeke, A., Li, A. P. L., Goerzen, A. (2009). Toward more effective research on the multinationality-performance relationship. Management International Review, 49(2), 149-161.

Vilas-Boas R., Suàrez-Gonzàlez I., (2007). Internationalization and Firm Performance: the S-Curve Hypothesis under the Eurozone context, Nuevas Tendencias en Direcciòn de Empresas, DT 15/07.

Welkowitz J., Cohen B., Ewen R. (2006). Statistics for the behavioral sciences, 6th edition, New York, Wiley.

West, G. P., Noel, T. W. (2009). The Impact of Knowledge Resources on New Venture Performance. Journal of Small Business Management, 47(1), 1-22

Williamson, O. E. (1979). Transaction-cost economics: the governance of contractual relations. Journal of law and economics, 22(2), 233-261.

Wright, M., Westhead, P., Ucbasaran, D. (2007). Internationalization of small and medium-sized enterprises (SMEs) and international entrepreneurship: A critique and policy implications. Regional Studies, 41(7), 1013-1030.

Yang, H., Lin, Z. J., \& Peng, M. W. (2011). Behind acquisitions of alliance partners: exploratory learning and network embeddedness. Academy of Management Journal, 54(5), 1069-1080.

Yeoh, P. (2004). International learning: antecedents and performance implications among newly internationalizing companies in an exporting context. International Marketing Review, 21 (4/5), 511- 535.

Zahra, S. A., Hayton, J. C. (2008). The effect of international venturing on firm performance: The moderating influence of absorptive capacity. Journal of Business Venturing, 23(2), 195-220.

Zahra, S.A., George, G. (2002). Absorptive capacity: A review reconceptualization, and extension. Academy of Management Review, 27 (2), $185-203$ 
Zahra, S.A., Ireland, R.D. Hitt, M.A. (2000). International expansion by new venture firms: international diversity, mode of market entry, technological learning, and performance. Academy of Management Review, 43(5), 925-950. 